\title{
LOCAL POLITICS POST-REFORM ERA: THE ROLES OF MUHAMMADIYAH IN THE 2004- 2014 DPD'S ELECTION IN YOGYAKARTA SPECIAL REGIONS, INDONESIA
}

\author{
Husni Amriyanto ${ }^{1}$; David Efendi ${ }^{2}$ \\ ${ }^{1}$ Department of International Relations Universitas Muhammadiyah Yogyakarta, Indonesia \\ ${ }^{2}$ Department of Public Administration and Government Affairs Universitas Muhammadiyah \\ Yogyakarta, Indonesia \\ 1 choenny@yahoo.com; 2 defendi83@gmail.com \\ DOI: https://doi.org/10.18196/jgpp.53103
}

Article Info

Article history:

Received 03 Nov 2018

Revised 05 Nov 2018

Accepted 30 Nov 2018

Keywords:

symbolic power, representation, electoral, Muhammadiyah, democracy.

\section{ABSTRACT}

After post-Reform Indonesia, Indonesia has been employing a dramatic decentralization practice in Indonesia nationwide. Since 1999, Indonesia has been electing for representative council (DPR $\mathrm{RI}$ ) and regional representation so called DPD RI in very direct way. This paper aims to analyse the local politics especially at the case of DPD's election in Yogyakarta special region of Indonesia in the competition process among the different group interests which are Islamic group (Muhammadiyah, NU, PKS), Kraton /aristocrat interest, and nationalist group interest (PDI-P). Those groups are the big four that have been playing important role in the competition in DPD election sequentially in 2004, 2009, and 2014. In Yogyakarta special region, four members of DPD since the first election has been represented by three Islamic group both modern and traditional ones and by Yogyakarta palace. this paper more focus on the 2014 election which were followed by more competitor from Pakualaman palace, and also from nationalist group that have same mass with the Palace. this competition was really interesting to explain, how people decide their representative members and how different group compete each other in this election. Also, what strategy and by manner they collect voters in this individual based-individual candidate election. From the field research, it can be concluded at least there are three point (1) each candidate was strongly endorsed by established organization and community to support for the election since 2004. So, four incumbents easy to win the competition; (2) the success team have many thing in common for example the focus on the core of supporter (basis masa) by using strategy "by name by address list"; and lastly (3) they were employing any symbolic that really easy to understand for the common people such as Islamic value, organization value, ideology, etc. by adopting many social activity and ritual in promoting candidates for example club goods, voluntary organization, and other forms of informal communities. 


\begin{abstract}
ABSTRAK
Setelah pasca-Reformasi Indonesia, Indonesia telah menggunakan praktik desentralisasi yang dramatis di Indonesia secara nasional. Sejak 1999, Indonesia telah memilih dewan perwakilan (DPR RI) dan perwakilan daerah yang disebut DPD RI dengan cara yang sangat langsung. Tulisan ini bertujuan untuk menganalisa politik lokal terutama pada kasus pemilihan DPD di Daerah Istimewa Yogyakarta di Indonesia dalam proses kompetisi antar kelompok kepentingan yang berbeda yaitu kelompok Islam (Muhammadiyah, NU, PKS), Kraton / aristokrat, dan kelompok nasionalis bunga (PDI-P). Kelompok-kelompok tersebut adalah empat besar yang telah memainkan peran penting dalam kompetisi dalam pemilihan DPD secara berurutan pada tahun 2004, 2009, dan 2014. Di wilayah Yogyakarta khusus, empat anggota DPD sejak pemilihan pertama telah diwakili oleh tiga kelompok Islam baik yang modern maupun yang yang tradisional dan oleh istana Yogyakarta. Tulisan ini lebih fokus pada pemilu 2014 yang diikuti oleh lebih banyak pesaing dari istana Pakualaman, dan juga dari kelompok nasionalis yang memiliki massa yang sama dengan Istana. Kompetisi ini sangat menarik untuk dijelaskan, bagaimana orang memutuskan anggota perwakilan mereka dan bagaimana kelompok yang berbeda bersaing satu sama lain dalam pemilihan ini. Juga, apa strategi dan dengan cara mereka mengumpulkan pemilih dalam pemilihan calon individu berbasis individu ini. Dari penelitian lapangan, dapat disimpulkan setidaknya ada tiga poin (1) masing-masing kandidat didukung kuat oleh organisasi dan komunitas yang mapan untuk mendukung pemilihan sejak 2004. Jadi, empat petahana mudah memenangkan persaingan; (2) tim sukses memiliki banyak kesamaan, misalnya fokus pada inti pendukung (basis masa) dengan menggunakan strategi 'berdasarkan nama berdasarkan daftar alamat'; dan terakhir (3) mereka menggunakan simbol apa pun yang benar-benar mudah dimengerti bagi orang-orang biasa seperti nilai Islam, nilai organisasi, ideologi, dll. dengan mengadopsi banyak aktivitas sosial dan ritual dalam mempromosikan kandidat misalnya barang klub, organisasi sukarela, dan bentuk lain dari komunitas informal
\end{abstract}

\title{
INTRODUCTION
}

Under the democratization project in Indonesia there are growing number of different types of political engagements among the people. Some of faith-based organization prefer to participate in such political 
party and in the same time they are ready to support candidates for regional representative council so-called DPD RI. But several Islamic groups remains 'apolitics'. The reasons why they are supporting candidate in individual elections are many. The main reason mostly it is about representative of the organizations to have their people in parliamentary assembly in the name of privilege of organization. Other reasons are about political access, financial resources, and to help organization in building network nationwide. Interestingly, there are a lot of organizations including political parties in Yogyakarta Special Regions claim themselves that they are appropriate to have candidate elected in the general election regularly. That is why in every $5^{\text {th }}$ year elections there are at least 10 13 candidates run for DPD RI in Yogyakarta.

One of significant reform demands is actually the decentralization of political power from the previous authoritarian regime whose power held for more than 32 years in the base of power, the capital city, DKI Jakarta. This demand afterward was institutionalized in a democratic mechanism that is with holding an election in local level to elect the local representatives for regional representation in national level. This regional representation (DPD) is a new institution that officially established in 2004. Many observers and scholars say that this new institution is replacing the local delegation in new order era. The existence of this institution furthers becoming a challenge regarding to the quality of political decentralization-whether DPD, in the same time, it would bring a region it represents to a better 
condition and able to reinforce the local government capacity in development .

In accordance to UUD 1945, the local representative council has several authorities as mentioned in below article 22D: ${ }^{1}$

1.) The local representative council can propose to house of representative a bill which related with local autonomy, relationship between central and local government, the proliferation and the unity of region/district, the natural resources management and other economy resources management, and also affairs related to budget balance between central and local government.

2.) DPD joins the discussion of bill draft that related to local autonomy; relationship between central and local government; The formation, proliferation and unification of a region/district; Management of natural resources and economy resources, and budget balance between central and local; and giving an advice/consideration to house of representative (DPR) regarding to the state budget draft (RAPBN) and other bills about tax, education, and religion.

3.) DPD can as well monitor the implementation of bill which related with local autonomy, relationship between

\footnotetext{
${ }^{1}$ This authority is also an authority after a decision from Mahkamah Konsitutsi (MK) IN 2013. DPD request to MK with number 92/PUUX/2012 is related to the examination of UU number 272009 about MPR, DPR, DPD, DPRD, and UU number 122011 about the formulation of constitutions towards UUD 1945.
} 
central and local government, the proliferation and the unity of region/district, the natural resources management and other economy resources management, implementation of state budget, tax, education, religion, and report the monitoring result to DPR as a consideration for taking an act.

DPD was first established in October 4 2014, when the first 128 members of DPD were inaugurated and taken their oath. In the beginning of its establishment, there were various challenges faced by DPD. Those challenges are varying from its authority which considered insufficient to become an effective second room in bicameral parliamentary system, to its lack of institutional capacity. Those challenges appeared especially due to the lack of political support given to this new birth institution.

The existence of local representation body in national parliament like DPD, was actually not a new fresh idea and the idea was appeared prior to independence era. This idea was initiated by Moh Yamin in UUD 1945 formulation assembly by national body which prepared all independence needs and affairs (BPUPKI).

The notion about the importance of local representation in parliament were first accommodated in Indonesia first constitution, UUD 1945, with a concept 'local delegation' in People assembly Council (MPR), that works along with 'party delegation' (DPR). This was regulated in the second article UUD 1945, that states "MPR is consists of DPR members and delegations from groups and regions, 
38. according to regulation stated in constitution." This loose in regulation in UUD 1945 was further regulated in various regulations in constitution.

This institution, according to political theory, is a territorial representative $^{2}$, consist of representations from all provinces (four representation for each province) and these representatives are elected together with legislative election. DPD election in 2004 generated 128 senators, in 2009 generated 132 senators, and in 2014 generated 136 senators of 34 provinces. This great numbers are expected to be able to speak for their people and their region interest.

This paper aims to discuss one of cases about how such a big Islam based mass organization in Yogyakarta, Muhammadiyah, was participating to determine representative from Yogyakarta in DPD RI. The other questions try to be elaborated in this paper is to analyze the motivation that triggers Muhammadiyah to mobilize its organization and how its structure machines are operationalized to win the prepared candidate in 2004, 2009, and 2014 election. Due to there are three different period of elections, this writing does not use the chronological approach in elaborating the idea yet it employs the comparative approach. The year or period would only become a mark to tell the involvement of Muhammadiyah, however, the essence is to

\footnotetext{
${ }^{2}$ The existence of DPD in Indonesia constitutional system could not be separated from the institutionalization of representation function. In order to institutionalize this representation function, there are three well known representation system and applied in various democracy countries: 1.) Political representative system; 2.) Territorial representative system; 3.) Functional representative system.
} 
answer the question of how Muhammadiyah can take its nominated candidate to Senayan.

In the internal of Muhammadiyah, there was a debate over the urgency of Muhammadiyah in promoting its talented cadre to DPD RI. Many cadres questioned the role and benefit that Muhammadiyah would gain with putting its cadre in DPD RI. There are several Muhammadiyah elites, even they are small in number, who doubts to promote any candidate from Muhammadiyah or even involve themselves in politics. Furthermore, there are also cadres who see the political effect of this involvement that can harm the harmony of ummah. On the other hand, there also many cadres who believe that having a representative in DPD RI is essential for Muhammadiyah. Interestingly, many cadres also have such imagination that an official endorsement from Muhammadiyah to its nominated candidate could be interepreted as Muhammadiyah's effort in contributing for the development of our nation.

As an insight, a candidate of DPD RI who is promoted by Muhammadiyah was once placed on the top position in gaining largest votes in 2004, yet placed on the bottom in 2009 and 2014 legislative elections. For the sake of exploring this dynamic, this research is aimed to answer how the concept of representation in accordance to Muhammadiyah elites in DIY in determining a candidate for DPD RI and also to explain critically how the internal dynamic of Muhammadiyah in the contestation of this electoral politics. 


\section{6 conceptualization}

The conceptualization of election and representation in this discussion is quite significant to develop the idea about particular things that may different from various concepts in different context. In this term, it is imperative to conceptualize several ideas; election, civil society, and strategy to win in politic of representation.

\section{(1) Election}

There are various perspectives in understanding whether DPD election is categorized as practical politics or not in Muhammadiyah members. Politic is often associated with the politic of party while the non-party election like DPD is often considered as non-practical politics.

Generally, people understand that election is an official and democratic transition of power and leader. Furthermore, election can also be used as 'reward and punishment' mechanism for the candidate. Therefore, if one seats in representation body through election process, so its representation would be considered as political representation including DPD member because even representative of DPD is territorial representative, the ones who are electing them are still a 'people'. Whatever the duty they hold in society, if they are working in representation body they would still be considered as political representatives.

Since April 52012 DPD RI has been declared as Indonesia senate. The senate conception is basically has two functions, which is representation and its position. Representation is a function in 
representing people and region while its position works for giving the second opinion/alternative from DPR opinion. Even as second line, it is expected that this institution would have some improvement in its strategic roles in responding the challenges of development in the regions especially in new proliferated region that would definitely be helped by the existence of its representation in DPD.

DPD RI is a new institution emerged from the wave of demands after the decline of Soeharto. It born in the new Indonesia constitutional system through the third UUD 1945 amendment and was decided by MPR RI in November 21 2001. DPD RI has functions, duties, and authorities that officially regulated in constitution. It is a representation body that represents a region and clearly has a significant and strategic position in Indonesia constitutional system to encourage the development process and the advancement of regions and also to actualize the check and balance system both with executive and among legislative body.

(2) Muhammadiyah as Civil Society

Muhammadiyah in DIY as social and religious organization is very old organization that born in 1912 and was initiated by Kyai Haji Ahmad Dahlan. It is often in political issue in which Muhammadiyah is involved or involves itself as organization mandate or as its elite political expression. Therefore, Muhammadiyah is feeling the necessary of having a representation in DPD RI since 2004 where DPD first established as a part of bicameral system. In the last three legislative elections, Muhammadiyah has always succeed to send its 
3:8 cadre to seat in DPD RI. That kind of patriotic role is considered as part of organization mandate especially a mandate from Tanwir Bali. In the history of politics, it's been always elite as the most determinant actor. Elite is defined as a social group who has highest index in society so they have influence and power in social political life. That index is mostly based on the income/richness, capability, and political power so they able to have control over a group of majority (Bottomore, 2006:1-2).

According to Pareto's political stratification, society consists of two classes, which are: The upper class, that also divided into the governing elite and non-governing elite. The second class is the lower class that usually classified as the non-elite class or more well known as 'mass'. According to Robert D Putnam, there are three ways to identify this class; analyzing position, reputation, and decision. Either formal or non-formal position is considered can make people as an elite since it can mediate and give a power attribute that afterwards managed in various ways. Furthermore, the reputation analysis tends to be more informal. Elite is viewed from how he/she is considered has an influence in its neighborhood, even when he/she has no position in society. The last is the decision consideration that emphasizes on the role of one in influencing the decisions making process in a group of society (Mas'oed and Mc Andrew 1995:91-94).

Operatively, the ones who identified as elite in Muhammadiyah DIY in this research are the 13 committees in PWM DIY, chairman of all autonomy organizations under Muhammadiyah (ortom)-Aisyiyah 
PM, NA, IMM, IPM, HW, and TS-, chairman of PDM in four regencies and one city in DIY and also the committee of LHKP PWM DIY as in charge body that responsible to lead as success team. In addition, there are also elites who lead the Muhammadiyah business units.

(3) Political Representation

Sociologically Muhammadiyah represents a middle class students/santri and modern Muslim groups. Muhammadiyah is spread to all provinces, regencies, and rural areas. As Islam group, Muhammadiyah could not simply categorized as urban Muslim group. This is proven by the distribution of Muhammadiyah business units such as school, mosque, and hospital in many rural areas. In accordance to a report written by Majelis Pustaka Informasi (MPI) IN 2010, Muhammadiyah has succeed to spread its role through its business units in the field of education and health that exceed more than a thousand.

In 2004, the new democracy canal in basic conception of bicameral system, apart from political party, where region can send their delegation/senator in an institution called DPD RI Muhammadiyah can use this situation as political opportunity to involve in formal 'power' arena of state. A discussion whether DPD RI is a political institution or not is still confusing Muhammadiyah members in the grass root. If this is viewed with political logic, there would be rejection from khitois/conservative ones who consider Muhammadiyah is basically should not play in practical politics. 
391 Moreover, there is an official letter or SK PP Muhammadiyah that clearly limits the procedural political movement. From one of key informants, the decision to nominate a candidate in DPD election was seen as political opportunity as conceptualized by McAdam (1999) and also discussed by Situmorang (2007) in his book social movement.

This infrastructure is crucial to position Muhammadiyah in political constellation in which other ideological groups are also compete over a position in representative body. Beside of these ideological representations, there are also non-ideological sides which are Keraton and Pakualaman. Particularly in 2014, PDIP tried to mobilize its political machine to get the DPD RI seats. However, in Yogyakarta context it was not too succeed due to its mass are separated and support the GKR Hemas (representing Keraton) or tradition group.

(4) Winning Strategy

Of three DPD elections periods, the strategy and tactic to win the candidate has not changed much. There were only some improvement and neater organizing that can be seen in a 2014 election process. More detail picture and situation of strategy used by Muhammadiyah in three elections $(2004,2009,2014)$ would be explained later.

\section{Methodology}

This study case based research is a descriptive qualitative research. To obtain a data, researchers examine documents both in mass media 
and in organization archives, and also conduct an interview with actor, success team, organization committee, any news and relevant documents. In addition, in the last DPD election in 2014, researchers were part of the competition therefore can be categorized as participant/participatory observation. As an insider, it is expected there will be an advantage in collecting sensitive and secret data intensively without facing the ethical problems in maintaining research objectivity. For election in 2014, this research is started since December 2013 until the election date in April 9 2014. The process of accessing data and media clipping was conducted between these two events (December 2013-April 2014).

Analytical technique and data interpretation in this research follows the steps recommended by John W. Creswell (2010:274-284), that the data analysis process is started with; 1) Examining all available data from various sources, which in this context is the success team or campaign team documents; 2) After examining all available data, the next is examining the validity of data and conducting data reduction which done with selecting the important data and should be investigated further; 3) The last is interpreting the data. This process consists of understanding and investigating deeply all collected data and afterwards narrating them in a written research report.

\section{findings}

Of three elections in encouraging its cadre to seat in DPD RI, Muhammadiyah has employed similar strategies and tactics from year 
392 to year. There were only some improvement and neater organizing that can be seen in a 2014 election process. All these efforts are conducted in term of representing Muhammadiyah in its patriotic roles as regulated in several materials of organization decision. In other words, putting Muhammadiyah cadre in DPD is in term of keeping the spirit of organization in its birthplace, the Yogyakarta special region.

In determining a candidate who will represent Muhammadiyah in DPD was never been an instant process. It went through a long process that should be passed so Muhammadiyah would really have its best cadre as representation of organization personally or by his/her voice in a policy making process. In DIY, the ones who decide organization representative are several chairman in regional level committee (PWM DIY) together with LHKP PWM DIY after collecting aspirations from Muhammadiyah members in both formal and cultural events.

In 2013, Muhammadiyah cadres through a decision in an regional assembly in DIY for the second time selected Muhammad Afnan Hadikusumo to be a candidate of DPD RI representing Muslim people in DIY for the period of 2014-2019. Previously, since 2009. 2014, Afnan was one of representatives from DIY in DPD RI. In addition, PWM DIY also has formed the success team which was coordinated by LHKP PWM DIY.

For more detail about how Muhammadiyah is encouraging its candidate to win the election, there were several strategies that 
improved and changed from three election period in 2004, 2009, and 2014. It is very obvious that the contemporary marketing politics tactic was influencing the way Muhammadiyah plays it politic. A famous political strategy which known as "by name by address" and used by many legislative candidates was also used in Muhammadiyah.

The role of ideology in this semi-politics process is frequently facing a complicated contestation. The reason of either pro and con of Muhammadiyah involvement in DPD RI election can be caused by the understanding about ideology in Muhammadiyah itself. Due to ideological consideration, ones rejected to join the success team of Afnan and vice versa. One of efforts taken by Muhammadiyah elites was with persuading people that the patriotic role of Muhammadiyah members is also suggested as written in hand book of Islamic life of Muhammadiyah members.

In the campaign material of PWM success team, there at least five reasons why Muhammadiyah promotes its cadre to seat in DPD RI. First, as organizational commitment in performing patriotism role as mandated in Tanwir Makassar. Second, as prove that Muhammadiyah is actively taking strategic role for the sake of region and Indonesia generally. Third, as a part of Ijtihad Politik particularly for Muhammadiyah members in DIY to have representative in DPD RI given to the fact that Yogyakarta is a symbol and capital city of Muhammadiyah. Fourth, as prove that Muhammadiyah always encourage its best cadre to optimize his/her role in all fields of life including in politics and government. The last, as manifestation of 
394 Muhammadiyah members aspiration in Yogyakarta as decided in regional assembly and also considering the support from Muhammadiyah cadres in the grass root.

The making of political identity sentiment and winning technique that emphasizes the organization networks are implemented from various lines such as the success team composition, strategy of mobilizing support from core ummah (cadre, family, etc), and society who receives service from Muhammadiyah either in social-religious activities, education, or in other sectors.

1. Success Team

In election 2004 where Warsito Utomo as a chief of PWM DIY and stand forward as success team was not really become an important talk since the organization structure still too strong so the branches in local level moved with organization logic in gaining votes from ummah. According to information found by researcher, 13 leaders of PWM DIY were directly going to the grass root to ensure the votes in branches. The pattern of team organizing was not too politics since it was handled directly by organization chiefs. In 2004, even political party has not recognized a professional winning team.

In this 2014 election, other candidates who basically from Muhammadiyah cadres got no significant votes such as Busyro Muqodas and Evi Latifah (A chairman of PP Aisyiyah). Other finding is Muhammadiyah won and succeed to send its candidate to DPD RI with spending small amount of money due to insignificant 
competition since every community was clear its candidate and its mass. Another factor is the existing political euphoria after reform era in which Amies Rais has pivotal role in national politics.

In 2009 election, Muhammadiyah has introduced a neater and more structured started from consensus in electing candidate-to determine the one and only candidate. The experience in 2009 apparently the losing candidate still go with another group which was PGRI (also failed). On the other hand, Afnan who won the consensus eventually got the seat in DPD RI even placed in the fourth position based on the voters. In 2014, due to external pressure from other communities that getting more professional (tandem, by name by address), Muhammadiyah tried to make an opinion war through campaign, social media, Islamic sentiment (gerakan sedekah suara), and also the using of voters list by name by address. These strategies and innovatios were expected to secure the vote even the result still placed Afnan in the fourth position. The next finding is the fact that the current voters at 2014 were more flexible and unpredictable. Several figures who supposed to support candidate from Muhammadiyah were giving their vote to Keraton side. Surprisingly, the members too, were asking permission for supporting GKR Hemas in the name of tradition.

\section{Mobilization of the structure}

Aris Madani as a chief of PDM Yogyakarta city said as quoted by Masduki (2015) in his research report:

"...structured Succes team were established in the branced and district 
of Muhammadiyah in order to win the competition and to introduced sleected candidate of DPD RI from Muhamamdiyah representation. In addition, this team must employ any possible way in Muhammadiyah to support this only one by inviting him to speak to the public or jamaah. The reason is to make people more confident to choose Muhammadiyah representation as senator."

One of the major power of Muhammadiyah in DIY is its strong structure foundation, bureaucratic, and solid from province level to the lowest institutional level. Furthermore, the other hierarchical structures are also exist in autonomy organizations that reach nine units total. Also for semi hierarchy structure within business units, councils and bodies in Muhammadiyah's neighborhood that is large in number. If these to be functionalized as political machine could make the existence of Muhammadiyah become stronger. This matter, which is believed among many of Muhammadiyah's leaders that whoever is nominated by Muhammadiyah will successfully, won the DPD RI competition seats.

There are numerous reasons that strong enough and mostly referred as legitimacy by the elites to convince its ummah the importance of Muhammadiyah in nominating candidate within DPD RI election that has been done and succeed since 2004, 2009, and 2014, which this decision supported by several motivations, such: (1) as the commitment of Muhammdiyah carrying out its nationalism role (mandate from Tanwir Muhammadiyah in Makassar and Denpasar); (2) as the real evidence of Muhammadiyah that always take the 
strategic role for the interest of region, country and nation; (3) as part of "political jihad" especially for Muhammidyah's society in D.I. Yogyakarta to have the representation in DPD RI in remembering that Yogyakarta is a symbol and Muhammadiyah's capital; (4) as the proof of Muhammadiyah continuously encourages best cadre to optimize its roles in every areas of life including politics and government; and the embodiment of Muhammadiyah people's aspirations on which has been decided through the deliberation at regional level with the consideration of supports and votes from Muhammadiyah's member in subsection, branch, and region. ${ }^{3}$

Furthermore, the communication with ummah under a very strong reason and incentive that being used is privilege reason which is Yogyakarta as the capital, birth place of Muhammadiyah, deserved to have representation in DPD because with this D.I Yogyakarta's Muhammadiyah will be considered solid in the eyes of Muhammdiyah's society in other regions in Indonesia through the the achievements in political representation.

A few important matters in the context of D.I. Yogayakarta's Muhammdiyah achievement successively placed its representation in the DPD seats three periods because of the network strength internal and externally. This "accomplishment" belongs only to D.I Yogyakarta's Muhammadiyah.

a. External Networks

\footnotetext{
${ }^{3}$ Materi kampanye internal Muhammadiyah; terdapat dalam buku panduan saksi yang diterbitkan oleh LHKP PW Muhammadiyah DI Yogyakarta, 2014
} 
398 One of Muhammadiyah external network considered as important enough is teacher organization (KORPRI) and PGRI which for so many decades admittedly been dominated by Muhammadiyah. Even more, Muhammadiyah's figure that failed to nominate the DPD via conversion in PWM finally could compete through the support of PGRI in 2009. in 2004 and 2009 Muhammadiyah had many DPD candidates meanwhile for 2014 there was just one incumbent candidate who is Drs M Afnan Hadikusumo. The importance of external network in 2014 was caused by a strong competition also the need for more votes to win the most second votes after GKR Hemas. For many elites the runner up place is a very important symbol for Muhammadiyah's identity affirmation in its basis region.

b. AMM's engagement

LHKP DIY as the front line that was involved for the winning of $\mathrm{M}$ Afnan in 2009 given evaluation by 2009, AMM movements (Angkatan Muda Muhammadiyah) to mobilize vote's support for the DPD measured as very minimalist (interview AD, 2 Februari 2015) hence in 2014 there is a demand for new format or new synergy that need to be implemented. It can be observed from the structure of campaign team, which almost accommodates all elements of Muhammadiyah, such autonom organization, council, institution or business unit in region or locality. The involvement of AMM then become more vibrant with the identity of Barisan 1912 to winning its Muhammadiyah candidate in DPD RI. 
What moves the AMM was originally nothing more than the sectarianism politics power (politik aliran) that face-to-face with PKS group which in essence has Islamic modernist base like Muhammadiyah. Not a few of Muhammadiyah's member who gives political support to the DPD candidate of PKS representation. This matter has trigged many AMM elites becomes more militant. One of their efforts was to make the candidate from Muhammadiyah acquired the second place after GKR Hemas. However, it could not be realized because not all Muhammadiyah's machine moves to maximize vote's support. Moreover, many have confident of Muhammadiyah's candidate winning.

c. Targetting Basis

In socialization material campaign DPD RI LHKP formulates a very focus campaign model that captured members in Muhammadiyah branch level and business units includes families that using "services" of Muhammadiyah's business units such as parents of student, patients and also patient's families member who seek treatment in Muhammdiyah's hospitals. In that material, clearly mentioned several positions of voter outside the core basis Muhammadiyah's board from region till branch and fron business units; from outside line of Muhammadiyah's board such sympathizer and general public also from other mass organization's community that sociologically not close to Muhammadiyah.

One of interesting argumentation on why "basis" strategy chosen, because the awareness of DPD RI electability from Muhammadiyah is 
11 a symbol of association not meant to give "promises" for non muhammadiyah constituent. At glance, inside vision mission of $\mathrm{M}$ Afnan Hadikusumo in 2014 was very visible with education and health which are a core business of Muhammadiyah for a century.

Strategy selection above shows that security model toward mass basis ideologically felt as part of group that associated with symbols and emotional closeness to Muhammadiyah. Rational strategy selection is necessary, however, efforts to build the political sentiment also important for captive market of Muhammadiyah's grassroots especially for groups that have the distance with the process of power politics. Usually this group is a citizen group and muhammadiyah's sympathizer who has low background in education. It was realize fully by the succession team so this group must be targeted with an approach model of sentiment or borrowing Arya Dwipana's (2009) term as sectarianism politics(politik aliran)-affiliation and political support not based on work lan of the candidate or its capacity except the emotional relation with the organization or certain ideologies.

\section{DISCUSSION}

DIY Muhammadiyah's choice nominating the DPD RI candidates is not without hurdles considering PP Muhammadiyah issuing organizational decision to prohibit Muhammadiyah practically involved in politics, including nominating DPD RI candidate openly by Muhammadiyah. In Yogyakarta, Muhammadiyah tries two times in general election proposed its candidate and succeed. This matter is necessary remembering three members composition of DPD RI from 
DIY that represents community group ideologies, which consist of the palace (keraton) as feudal power supported by traditional community, traditional Islamic represents by NU, modern Islamic affiliates with PKS (partai keadilan sejahtera). Seeing the big chance of Muhammadiyah in DIY, involvements of Muhammadiyah in the contestation to compete over organization representative has become a rational choice.

Muhammadiyah, sees general election as meaningful political process, strategic, also determine existence, direction and nation future and Indonesian country. Election is not a political ritual and mere leadership succession, but the momentum of political jihad and substantive means of establishing democracy and ending the Transitional and all forms of political experiment that has been considered increasingly distanced national life of the noble mission of reform and national goals 1945 .

For that purpose, PP Muhammadiyah gives statement to mean the election process in 2014. Muhammadiyah encourages and strive together with all other components of the nation makes the 2014 elections as a milestone for;(a) generates legislative member (DPR, DPRD and DPD competent and trustworthy as well as national leaders (president and vice president) who has a certain character, strong personality, reformers, visionaries, and serve and capable of solidarity, solve problems and take risks; (B) end the corrupt practice of procedural-transactional and partisan power oriented, primordial, and the feudalistic and the beginning of the consolidation of civilized 
102 multicultural democracy; (C) uphold Indonesia based on on Pancasila, the opening of the constitution of 1945 and the single berbhineka ika in the frame of the Unitary Republic of Indonesia with a way to run the country the right to make Indonesia advanced, equitable, prosperous, dignified and sovereign.

2014 was an event of the third regional representative (DPD RI) selection since the post-reform, which began in 2004. On the simultaneously election between legislative and DPD RI in2014 results showed a victory by all incumbents that each consider to represents the basis of ideological or cultural differences. As for the data of votes from 13 candidates elected sampled into 4 can be seen as follows.

TABLE I. HASIL PEROLEHAN SUARA DPD RI TAHUN 2009 DAN 2014

\begin{tabular}{|c|c|c|c|}
\hline \multirow{2}{*}{ NAMA OF CANDIDATES } & Affiliation & 2009 & 2014 \\
\hline GKR Hemas & Aristocrat/sultanate & 941.153 & 1.017 .687 \\
\hline M Afnan Hadikusumo & Muhammadiyah & 106.117 & 144.820 \\
\hline Cholid Mahmud & PKS/islamic group & 181.415 & 149.824 \\
\hline Hafidz Ashrom & Nahdlotul Ulama & 171.108 & 158.794 \\
\hline
\end{tabular}

Sumber: KPUD DIY

Off the 4 elected members of DPD in 2009. Two old members are GKR Hemas and Hafid Asrom (NU). New faces of vice DPD RI from Yogyakarta are Cholid Mahmud (PKS) and Afnan Hadikusumo (Muhammadiyah). Considering from the result, PKS Yogyakarta has made remarkable progress by passing one of the best cadre to become 'ambassadors' of jogja community for DPD RI. As notes, in election 
2004 PKS Jogja did not promote cadres and only support one of the candidates who have proximity with the PKS but did not manage to qualify for Senayan.

Meanwhile the entirety data acquired from DPD RI DIY votes on all candidates in the 2014 elections can be seen below.

TABLE II. THE RESULT OF 2014 DPD ELECTION OF DIY

\begin{tabular}{|c|c|c|}
\hline \multirow{2}{*}{ NAMA OF CANDIDATES } & Affiliation & 2014 \\
\hline GKR Hemas & Aristocrat/sultanate & 1.017 .687 \\
\hline M Afnan Hadikusumo & Muhammadiyah & 144.820 \\
\hline Cholid Mahmud & PKS & 149.824 \\
\hline Hafidz Ashrom & Nahdlotul Ulama & 158.794 \\
\hline Sidarta Danusubroto & Nationalist/pdip & 79.845 \\
\hline Ismarindayani & Aristocrat/Pakualaman/democrat & 89.009 \\
\hline Fairus Ahmad & Nahdolutul Ulama & 60.842 \\
\hline Taufiqurrahman & Nahdlotul ulama & 53.714 \\
\hline Abdul Muhaimin & Nahdlotul Ulama & 48.885 \\
\hline Suratman & Nationalist & 16.856 \\
\hline Fidelis Indriarto & Christian & 77.065 \\
\hline Muhammad Hirsam & Nationalist & 21.274 \\
\hline
\end{tabular}

Sumber: KPUD DIY

One of the competition uniqueness within 2014 election was the aristocrat appearance of more than one basis of kingdom and also by the nomination DPD RI candidate from capital with the nationalist background Danusubroton who is incidentally the chairman of MPR RI that also acts as central board of DPP PDI Perjuangan. This candidate has special proximity with the ruler of Bantul, Idham, Samawi that predicted in that time would attract fanatic voters of GKR Hemas. 
114 As an illustration on how the representation of politics formed or modeled within the competition of DPD RI member in DIY can be seen from the elected candidate's profile. First, GKR Hemans is the consort of the kif Sri Sultan Hamengkubuwana X, who is the Kig of Kasultanan Yogyakarta since 1998 dan the governor or Daerah Istimewa Yogyakarta since 1998. Since 2004, GKR Hemas became the member or DPD RI with the origin of DI Yogyakarta Province and served as the vice of DPD chairman period of 2009-2014 and 2014-2019. Since then she always obtained largest votesin DIY for DPD RI which mostly used to justify how strong the influence of traditional power.

Second, Drs, H. A. Hafidh Asrom, M,M constitutes as the member of DPD RI DI Yogyakarta representation who has been the DPD RI member throughout three periods , 2004-2009, 2009-2014, and 20142019. However, in his official profile not much affiliated to NU and actually has much special proximity within the circle of Nahdiliyin especially in cultural lane. Third, Afnan Hadikusumo. Ever since childhood he was growing in the Muhammadiyah's village in kauman central Yogyakarta. From there his organization activities and experiences forged and also his profession background. Various positions within autonom organization dan Muhammadiyah he has finished. This confirms his identities as a Muhammdiyah representation in the competition of DPD RI. His politics experiences started from PAN committee and member of DPRD 
DTIY. Since 2010, Afnan aslo became the member of LHKP PWM DI Yogyakarta.

Last, Ir. H. Cholid Mahmud, ST, M.T is a politician from PKS as the DPD DIY 2004-2009. He is known as Ustadz and da'I. Cholid Mahmud was once became the chairman of Jama'ah Shalahuddin UGM, active in DDII representation of DIY, vice chairman of Yayasan Kajasha UGM, as an Advisory Board PW IKDI DIY, and also works as lecturer in technical faculty University of Cokroaminoto Yogyakarta. He also has the boarding school Mahasaiswa Islamic Centre Al-Mutadin, Seturan, Yogyakarta.

From many strategies that have been done by the success team "Barisan 1912" to deliver Afnan Hadikusumo in 2009 as well as 2014 there is the contestation of the use of symbol (mobilization od voter through Muhammadiyah or Islamic solidarity) and second, there was utilization the strength of families origin or charismatic power of $\mathrm{Ki}$ Bagus Hadi Kusumo.

The use of Islamic identity and Muhammadiyahm foe example, through alms vote movement or infaq vote could ensure to the followers of the goodwill in the political process of this senator election. Othen than incumbent have advantage in many things. This matter supported by the amar maruf nahi munkar movements that had been done by Muhammdiyah. Which means, Afnan sought as a figure who able to implement amar ma'ruf nahi munkar. From his track records, which so far from moral scandal made the socialization, activities within Muhammadiyah's forum went easy. 
406 People then could undoubtedly says that choosing him not solely as a candidate matter but because of Muhammadiyah (from various interviews).

This phenomenon of 'symbolic power' in accordance with the ideas of Benedict Anderson as the imagine community-as the development of common identity. In Muhammadiyah bond, although no blood relation between a people with others, in a place that very far away, however, they have connection that bridged by this organization, same origins, or same religion. That resemblance took as the material by the success team of Muhammadiyah in order to gain many votes when elections. Not only ideological bonds, but also between educational service provider of Muhammadiyah with its service users.

Whereas the factor utilization of charismatic family which is Afnan as the grandchildren of a moderate national hero and can be accepted by general public. In spite of that, the name of Hadikusumo able to be a force of its own memorabilia for constituents, especially here Afnannot only has similarity in name but also as grandchild of a national hero which by other competitors this strong image they do not have. Moreover his other competitor is came from the group of santri and also have the basis of santri then it become very small for the possibility for other candidates to pick on the big name of Hadikusumo, besides having the title of national hero ki bagus Hadiksusmu had history as preacher who highly respected at the national level. 


\section{CONCLUSION}

DPD RI candidate that has been submitted by Muhammadiyah must come from the element of association cadre who have long been active, not an individual who suddenly appears, and that matter proven with the list of names raised by each Pimpinan Daerah Muhammadiyah (PDM) and nomination by PWM DIY. After those names screened by PCM and PDM collected, will be held a special forum named Musyawarah Pimpinan Wilayah (Muspimwil) in chosing the best nomine to be the representation of Muhammadiyah. Furthermore, the candidate not just enough by only active as Muhammadiah cadre, the individual who will represents Muhammadiyah must have wide-range knowledge related to public policy issues and able to stand up for the nation's interests in senate institution.

After the long process, then the name of Afnan Hadikusumo appeared with the incumbent status to be back as Muhammadiyah's representation in DPD RI. Afnan judged as the right candidate to be the representation of Muhammadiyah to be compared with other names, which appeared to the surface because he has long history as a Muhammadiyah cadre and considered have the experience also capable knowledge to sit in the DPD RI seats. In addition to these reasons, there is also capable cadre like Henry Zudianto, but he was unwilling.

A thesis of Muhammadiyah not the organization that designed for political power struggle in public area is still relevant. DIY Muhammadiyah been three times of DPD RI election nominating candidate with the motivation that encourage more on sentiment 
408 factor and emotional than legal-rational within recruitment of candidate till winning. Which means, the importance to protect pride and dignity of the organization in the eyes of DIY society and outside DIY is dominant till no considered only one eye by other political communities in Yogyakarta such NU and particularly PKS. Likely, the competitor of Muhammadiyah's candidate is not NU or the palace but candidate from PKS. The existence of external competitor motivates Muhmmadiyah to try mobilize its organizational resource to win the competition (votes above PKS).

Effort to win the candidate from Muhammadiyah to be more superior than PKS should be failed in 2014 caused by Muhammadiyah's machine have responded mediocrely toward election till there was no proper preparation and systematic to gain votes. This matter once more become corrector that Muhammadiyah's people not too much aware of political business chiefly the Muhammadiyah's decision maker elites like in AUM, autonom organization, Muhammadiyah in the regional level till branch. The sectarianism politics in Muhammadiyah marked with the character when election ended then it is considered finished and return to work for organization routines.

This study have not found a certain design in the internal Muhammadiyah to strengthen the DPD institution to be used as Muhammadiyah's missionary endeavor. This is caused by the view that for Muhammadiyah's people, politics representation important however, the businesses are return to the personal or the winning candidate. Representation concept in Muhammadiyah is more symbolic rather than political advocacy. This DPD case can be shown 
from there is no institution design to support program or DPD's member performance of Muhammadiyah representation in postelection. It means that DPD RI can be understood as elite representation rather than organization or public interest representation (ummah).

\section{REFERENCES}

\section{$\underline{B o o k s}$}

Alfian. 1989. M uhammadiyah: The Political Behavious of a M uslim Modernist Organization Under Dutch Colonialism. Yogyakarta: Gajah Mada University Press.

Anderson, Benedict. R.OG.1990. Language and power: exploring political culture in Indoensia. New York: Cornell University Press.

Azizah, Nurul. 2013. Artikulasi Politik Santri dari Kyai M enjadi Bupati (Political Articulation from Santri to become Kyall). Yogyakarta: Pustaka Pelajar dan STAIN JEM BER Press.

Bottomore, T. B. 2006. Elite dan Masyarakat (Elite and Society). Terj (Translation). Abdul Haris dan Syaid Umar, Jakarta: Akbar Tandjung Institute. Rosdakarya.

Dillistone, F. W. 2002. Daya Kekuatan Symbol (The Power of Symbol). Yogyakarta: Penerbit Kanisius

Dwipayana, Ari. 2009. Opini: Politik Aliran di Indonesiaa. Dimuat di surat kabar harian Kompas. (Opinion: Sectarianism Politics in Indonesia. Published in daily newspaper Kompas.

Erb, Maribeth and Priyambudi, S. 2009. Deepening democracy in Indonesia: Direct Election for the Local leader (Pilkada). Singapore: ISEAS.

Hambali, Hamdan. 2011. Ideologi dan strategi Muhammadiyah (Ideology and Strategy of Muhammadiyah). Yogayakarta: Suara Muhammadiyah.

Jurdi, Syarifudin. 2004. Elite Muhammadiyah dan Kekuasaan Politik: Studi Tentang Tingkah Laku Politik Elite Lokal M uhammadiyah Sesudah Orde Baru (Elite Muhammadiyah and Political Power: About the Local Elite of Muhammadiyah Political Behavior post-new order). Yogyakarta: Gadjah Mada University Press.

Keller, Suzane. 1995. Penguasa dan Kelompok Elit (Ruler and Elite Group). Jakarta: Raja Grafindo Persada.

Louw, Eric. 2005. The M edia and Political Process. London : Sage Publication.

Maliki, Zainudin. 2010. Sosiologi Politik (Sociology of Politic), Yogyakarta: Gadjah Mada University Press 
Mas'oed, Mohtar and Mc Andrews, Collin (Eds.). 1995. Perbandingan Sistem Politik (Political System Comparation), Yogyakarta: Gadjah Mada University Press

LeDuc, Lawrence, Niemi, Richard G, Norris, P. 2010. Comparing Democracies 3: Elections and Voting in the $21^{\text {st }}$ Century. California: Sage Publications inc.

Lexy J. 2001. Metodologi Penelitian Kualitatif (Qualitative Research Methodology). Bandung: REmaja Rosdakarya.

Salim, Agus. 2006. Teori dan Paradigma Penelitian Sosial (Theory and Paradigm of Social Research). Yogyakarta: Tiara Wacana.

Syaifullah. 2015. Pergesaran Politik Muhammaidyah (Muhammadiyah's Political shift). Yogyakarta: Psutaka Pleajar.

McAdam, Doug. 1999. Political Process and the Development of Black Insurgency, 1930-1970. Chicago and London: The University of Chicago Press

Majelis Pustaka dan Informasi Pimpinan Pusat Muhammadiyah. 2010. Profil Muhammadiyah (Profile of Muhammadiyah). Yogyakarta: M PI

Muchtarom, Zaini. 1988. Santri dan Abangan di Jawa (Santri and Abangan in Jawa). Jakarta: INIS

Qodir, ZUly. 2013. HTI dan PKS Menuai Kritik: Perilaku Derakan Islam Polik Indoensia (HTI and PKS reap Criticism: Indonesia Islamic Political Movement Behavior). Yogyakarta: JKSG

Situmorang, A. Wahib. 2007. Gerakan Sosial: Teori dan Praktik (Social M ovements: Theory and Practice). Yogyakarta: Pustaka Pelajar.

\section{Documents}

Surat Keputusan PW Muhammadiyah No Tentang Tim Pemenangan DPD RI 2014-2019. (PW Muhammadiyah Decree No. about Success Team of DPD RI 2014-2019)

Buku saku relawan dan saksi pemilu DPD RI diterbitkan oleh LHKP PW Muhammadiyah DI Yogyakarta. (Pocket Book of volunteers and election witness DPD RI, published by LHKP PW Muhammadiyah DI Yogyakarta)

Visi Misi Adnan Hadikusumo (disiapkan oleh tim pemenangan DPD RI, LHKP PW Muhammadiyah DIY). (Adnan Hadikusumo's Vision and Mission [prepared by success team of DPD RI, LHKP PW M uhammadiyah DIY])

Online Resources

Inilah anggota DPD RI terpilih (this is the elected member of DPD RI). Diakses pada tanggal 6 Januari 2014 dari: (accessed on January 62014 from:) http://www.pkspiyungan.org/2009/04/hasil-akhir-dari-dpd-ri-propinsi$\underline{\text { di.html }}$ 